\title{
Comment
}

\section{Are We Violating the Human Rights of the World's Poor?}

\author{
Thomas Pogge ${ }^{\dagger}$
}

\section{INTRODUCTION}

Answering the title question requires explicating its meaning and then examining the empirical evidence. The first task is begun in this introductory Part I, which gives a rough account of the two groups whose relation is to be queried: the world's poor and the "we" addressed in the piece. Part II then proposes a specific understanding of what it means to violate human rights. I will argue that a human rights violation involves non-fulfillment of human rights as well as a specific causal relation of human agents to such non-fulfillment. Importantly, this understanding of a human rights violation includes not only interactional violations (perpetrated directly by human agents) but also institutional violations (caused by human agents through the imposition of institutional arrangements). Based on the explication of the question in Parts I and II, Part III goes on to consider some of the evidence relevant to answering the question. This evidence favors the conclusion that there exists a supranational institutional regime that foreseeably and avoidably produces massive human rights deficits. By collaboratively imposing this institutional scheme, we are indeed violating the human rights of the world's poor.

Who, then, are the world's poor? Following the Universal Declaration,

\footnotetext{
† Leitner Professor of Philosophy and International Affairs at Yale University, Professorial Fellow at the Australian National University Centre for Applied Philosophy and Public Ethics (CAPPE), Adjunct Professor at the University of Central Lancashire, Research Director at the Oslo University Centre for the Study of Mind in Nature (CSMN) and a member of the Norwegian Academy of Science. Having received his Ph.D. in philosophy from Harvard, Thomas Pogge has published widely on Kant and in moral and political philosophy. His most recent book is POLITICS AS USUAL (2010). His current work is focused on a team effort toward developing a complement to the pharmaceutical patent regime that would improve access to advanced medicines for the poor worldwide (www.healthimpactfund.org). Professor Pogge is grateful to Tienmu Ma, John Tasioulas, and Lynn Tong for many valuable comments and suggestions on this piece.
} 
we might define a poor individual as one who does not have access "to a standard of living adequate for the health and well-being of himself and of his family, including food, clothing, housing and medical care." 1 This is a vague definition, but it clearly includes a large percentage of the world's population. In 2005, the median annual income was $\$ 465$, which means that half the world's people were living on less than $\$ 9$ a week (the global average weekly income was $\$ 66$ ). This surely sounds like poverty, but one must bear in mind that basic foodstuffs may cost in a poor country only half, a third, or an even smaller fraction of what they cost in the United States. So, depending on the prices of basic necessities in the various poor countries, some in the poorer half may plausibly be said to enjoy (and some in the top half to lack) an adequate standard of living. Still, such plausible adjustments do not alter the fact that a large percentage of the world's people lack the income necessary for basic survival and sustenance according to the Universal Declaration's definition. This includes almost all those who, in 2005, belonged to the poorest thirty percent of humanity and thus lived on less than $\$ 4$ a week. Even with substantially lower prices of basic necessities, their standard of living cannot plausibly be deemed adequate. ${ }^{2}$

By "we" I mean citizens of developed countries (e.g., the United States, the European Union, Japan, Canada, Australia, and New Zealand) who have sufficient mental maturity, education, and political opportunities to share responsibility for their government's foreign policy and for its role in designing and imposing supranational institutional arrangements. This definition takes for granted that the citizens of each of the included countries share a collective responsibility for what their government does in their name. This responsibility is not shared by all citizens, however.

1. Universal Declaration of Human Rights, G.A. Res. 217 (III)A, art. 25, U.N. Doc. A/RES.217(III) (Dec. 10, 1948).

2. The data used in this paragraph were kindly supplied by Branko Milanovic of the World Bank in a personal e-mail communication on April 25, 2010. He calculated the 2005 median as $\$ 465$ per person per year and the thirtieth percentile as \$211. E-mail from Branko Milanovic, principal economist in the World Bank's Development Research Group, World Bank (Apr. 25, 2010) (on file with author). Milanovic is the leading authority on the measurement of inequality, and his published work contains similar albeit somewhat less updated information. See generally Branko Milanovic, True World Income Distribution, 1988 and 1993: First Calculation Based on Household Surveys Alone, 112 ECON. J. 51, 51-92 (2002); BRANKO MILANOVIC, WORLDS APART: MEASURING INTERNATIONAL AND GLOBAL INEQUALITY (2005); BRANKO MILANOVIC, THE HAVES AND THE HAVE-NOTS: A BRIEF AND IDIOSYNCRATIC HISTORY OF GLOBAL INEQUALITY (2011). Inequality and poverty data are usually adjusted according to purchasing power parities (PPPs). I reject this practice as unjustified in the case of inequality because it conflicts with revealed-preference data: affluent people who could easily move to cheaper locations do not do so, and this shows that they get something of value in return for the higher prices they pay for the goods and services they consume. In the case of poverty measurement, a price adjustment is indeed appropriate. But the PPPs for individual household consumption expenditure commonly used for this purpose are inappropriate here because they reflect the prices of all the goods and services that households worldwide consume and thereby give far too little weight to the prices of basic foodstuffs, which are cheaper in poor countries but not as much cheaper as PPPs suggest. For detailed analysis, see Thomas Pogge, Politics as Usual: What LiES BeHINd the Pro-PoOR RHETORIC 79-85, 213 n.127 (2010) [hereinafter POGGE, POLITICS AS UsUAL]. 
Children are clearly excluded, and so are people with serious mental disabilities. I am not willing to go further and exclude additional citizens on account of their low income or poor education. If poor or poorly educated citizens recognize such a responsibility and act on it - much like the vastly poorer and vastly less educated workers of Manchester did when they risked their livelihoods to join the anti-slavery movement in 1787 then who has the standing to tell them that they are mistaken, that they have no such responsibility and need not bother? On the other hand, I am also not prepared to point the finger at a laid-off steel worker or struggling single mother in today's United States, for example, and pass judgment on whether she is failing to live up to her citizen responsibilities. ${ }^{3}$ I can suspend judgment about such cases because what matters is the judgment each of us reaches about ourselves. I believe that I share responsibility for what my country is doing in the name of its citizens, and I explain what human rights deficits I hold myself co-responsible for, and why. You must judge for yourself whether you find these reasons compelling or whether, on reflection, you find yourself sufficiently immature, uneducated, or impoverished to be exempt from the ordinary responsibilities of citizenship.

\section{What Does It MeAn to Violate A Human Right?}

In this Part, I will elaborate on my understanding of what it means to violate a human right. Human rights violations involve both the nonfulfillment of a human right and a certain causal responsibility of human agents for this non-fulfillment. These two aspects of human rights violations are treated respectively in Sections A and C. Section B is a brief interlude on the normativity of human rights: their relation to morality and the law. Section D concludes Part II by discussing the concept of a human rights violation emerging from the preceding sections.

\section{A. Non-fulfillment}

A particular human right of some particular person is unfulfilled when this person lacks secure access to the object of that human right. This object is whatever the human right is a right to: for example, freedom of movement, equal political participation, basic education, or freedom from assault. With regard to the human rights of the global poor, the most immediately relevant human right is the one already cited in Part I: the right to secure access to an adequate standard of living. But it is not the only one. Those who lack secure access to an adequate standard of living typically lack secure access to the objects of other human rights as well. For example, many people are compelled by poverty to enter employment

3. This topic has been the subject of an exchange between Debra Satz and myself. See Debra Satz, What Do We Owe the Global Poor?, 19 ETHICS \& INT'L AFF. 47, 50-51 (2005); Thomas Pogge, Severe Poverty as a Violation of Negative Duties, 19 ETHICS \& INT'L AFF. 55, 80-83 (2005). 
relations in which they are subject to serious abuse by factory supervisors or domestic employers. Many women are exposed to assault and rape because they cannot afford to divorce their husband, cannot afford a secure dwelling, or must fetch water from distant locations. Others are sold into prostitution by their own relatives or fall prey to traffickers who abduct them or promise them a living wage abroad. Most poor people are vulnerable to humiliation, dispossession, or personal domination because they lack the means to defend their legal rights.

What then is the normative significance of the empirical distinction between fulfillment and non-fulfillment of a particular human right of a particular person? By asserting a human right to some object, one is making at least the following two claims. First, one is claiming that it is of great importance that human beings should have secure access to this object - that such secure access serves important interests of the right holder or other human beings. ${ }^{4}$ Second, one is claiming that these important interests justify some significant duties on the part of other human agents to ensure that human beings actually have secure access to the objects of their human rights. The second claim fails in cases where security of access cannot be affected by human conduct: human beings cannot, at present, ensure immortality or perfect memory, for instance. And it also fails in cases where the counterpart obligations would be too onerous in the world as we know it: much or all of the importance of the interest in secure access to sexual intimacy is offset by the burdens that assuring such secure access would place upon other human agents.

That a human right exists presupposes that the second claim can be made good. But it does not follow that such counterpart obligations exist whenever this human right is unfulfilled for any person. When a person is without food or shelter far from any other human agent, her human right to an adequate standard of living may be unfulfilled even while there are no obligations on the part of others because none of them can reach her to supply what she lacks. A similar conclusion seems compelling when a person is without food or shelter in a social context where all other human agents in a position to assist her are likewise desperately short of these necessities. Here rendering assistance is too onerous to be required. But such scenarios do not undermine the case for the existence of the human right in question because it is not true across the board that there are never any counterpart obligations. This world clearly is one in which, when human beings lack access to a minimally adequate standard of living, there typically are other human agents who can plausibly be deemed required to help ensure secure access. It is also clearly of great importance that human beings should have secure access to minimally adequate shares of basic necessities such as food, clothing, housing, and medical care. And so the human right asserted in Article 25 of the Universal Declaration is well

4. The freedom of speech and expression, for example, is important not merely to those who would communicate, but also to all those who have such communications available to them or gain when injustice and ill treatment are deterred by the fear of publicity. 
grounded even if its non-fulfillment does not trigger obligations in each and every case. ${ }^{5}$

This same point can be made in terms of a distinction between duties and obligations. Duties are general; obligations are specific. For example, someone may have a general duty to keep her promises and a derivative obligation to return a book to her colleague. A duty may generate obligations only in certain circumstances: one's duty to keep one's promises generates no obligations if one has made no promises, for instance; and one's duty to give, when one reasonably can, food to hungry persons generates no obligations when there are no hungry people or when one is desperately short of food oneself. Though there is no obligation in these situations, this does not defeat the assertion of the duty so long as this duty does generate obligations in other situations that do or realistically can arise in the world as we know it. By contrast, there is no duty to give others immortality, because in our world no situations can arise in which such a duty would generate a plausible obligation.

What, then, are the duties correlative to a human right and, more specifically, correlative to the human right to a minimally adequate standard of living? A good step toward answering this question involves examining the respect-protect-fulfill triad that has become a staple of international agency thinking in this area. This triad goes back to Henry Shue's seminal book Basic Rights, which argues that each basic right gives rise to three distinct correlative duties:

I. To avoid depriving

II. To protect from deprivation

1. By enforcing duty (I) and

2. By designing institutions that avoid the creation of strong incentives to violate duty (I)

III. To aid the deprived

1. Who are one's special responsibility

2. Who are victims of social failures in the performance of duties (I), (II-1), (II-2) and

3. Who are victims of natural disasters. ${ }^{6}$

Inspired by this typology, Philip Alston and Asbjorn Eide popularized the respect-protect-fulfill triad in the 1980s. ${ }^{7}$ This triad was then carefully elaborated in the famous General Comment 12, adopted in 1999 by the UN Committee on Economic, Social and Cultural Rights. Article 15 of this

5. Universal Declaration of Human Rights, G.A. Res. 217 (III)A, art. 25, U.N. Doc. A/RES.217(III) (Dec. 10, 1948).

6. Henry Shue, Basic Rights: Subsistence, AfFluence, and U.S. Foreign Policy 60 (2d ed. 1996) (1980).

7. For their work and for their acknowledgement of Henry Shue's influence upon it, see, e.g., Philip Alston, International Law and the Right to Food, in FOOD AS A HuMAN RIGHT 162, 169174 (Asbjorn Eide et al. eds., 1984); See generally THE RIGHT TO FOOD (Philip Alston \& Katarina Tomaševski eds., 1984). 
General Comment reads as follows:

The right to adequate food, like any other human right, imposes three types or levels of obligations on States parties: the obligations to respect, to protect and to fulfill. In turn, the obligation to fulfill incorporates both an obligation to facilitate and an obligation to provide. The obligation to respect existing access to adequate food requires States parties not to take any measures that result in preventing such access. The obligation to protect requires measures by the State to ensure that enterprises or individuals do not deprive individuals of their access to adequate food. The obligation to fulfill (facilitate) means the State must pro-actively engage in activities intended to strengthen people's access to and utilization of resources and means to ensure their livelihood, including food security. Finally, whenever an individual or group is unable, for reasons beyond their control, to enjoy the right to adequate food by the means at their disposal, States have the obligation to fulfill (provide) that right directly. This obligation also applies for persons who are victims of natural or other disasters. ${ }^{8}$

These reflections largely accept two limitations that are widely taken for granted in the world of international relations: namely that human rights impose counterpart duties only on states and that the human rights of any person normally impose counterpart duties only upon the state or states under whose jurisdiction she falls either through physical presence or through a legal bond of citizenship or residency. ${ }^{9}$ I highlight these limitations because I will later question them along with the comfortable belief they sustain: namely, that the unfulfilled human rights of impoverished foreigners abroad impose human-rights-correlative obligations only upon their respective governments and compatriots and none upon ourselves.

\section{B. Human Rights in Relation to Law and Morality}

Since World War II, an impressive body of human rights law has emerged both internationally and in many national jurisdictions. Those who have been part of this process would concede that existing human

8. Comm. on Econ., Soc., and Cultural Rights, General Comment on The Right to Adequate Food, art. 11, U.N. Doc. E/C.12/1999/5 (May 12, 1995) [hereinafter General Comment 12], available at http://www2.ohchr.org/english/bodies/cescr/comments.htm (follow "12 The Right to Adequate Food (art. 11)" hyperlink).

9. Most would probably be willing to add here that the human-rights-based obligations of states also extend to any territories they attack, invade, or occupy and to the human beings residing there. On this somewhat controversial extension, the state of Israel would be responsible for the fulfillment of human rights in the Occupied Territories and the United States would be responsible for the fulfillment of human rights in occupied Iraq, Afghanistan, Guantanamo Bay, and a few hundred official and secret bases it maintains and controls around the world. 
rights law is neither complete nor perfect and remains to be ratified and fully accepted in many places. Despite these acknowledged shortfalls, one may sound arrogant when expressing a fundamental disagreement with the existing understanding of human rights which plainly includes the two limitations just highlighted - like a baseball player who, when told "three strikes and you're out," replies that he disagrees with this rule.

Human rights are different from baseball rules and, indeed, from most of national and international law. The difference is brought out by the fact that human rights are not merely part of the law but also a moral standard that all law ought to meet and a standard that is not yet met by much existing law in many countries. Law has incorporated human rights in a way that points beyond itself: to a normativity that does not depend on the law for its existence and cannot be revised or repealed by legislative or judicial fiat or by other law-making mechanisms such as treaties or international custom. This point is articulated in the legal separation from customary international law of ius cogens, a set of norms whose validity is understood to transcend the discretion of states. Ius cogens is generally taken to include at least norms prohibiting aggressive war, genocide, slavery, torture, military aggression, and piracy. ${ }^{10}$ The point is also prominently expressed in many legal documents, for instance in the very first words of the Universal Declaration of Human Rights, which call for the "recognition of the inherent dignity and of the equal and inalienable rights of all members of the human family" (my emphases). ${ }^{11}$ With this formulation, echoed in frequent appeals to "internationally recognized human rights," governments present themselves as recognizing certain rights in law rather than as creating these rights de novo. Their use of the word "inalienable" reinforces this conclusion: an inalienable right is a right that its holders cannot lose, not through anything they do themselves (waiver or forfeiture), nor through anything others do, for instance through an alteration of the law. National and international human rights law is then remarkable not only for its content - the uncompromising insistence, against all power and privilege, on the dignity of every human being - but also for its self-restraint. Human rights law is not declaring itself the source

10. A similar and related instance of law pointing beyond itself is the legal distinction between mala in se and mala prohibita. While there is disagreement about how exactly to draw this distinction, there is near unanimous agreement that there are mala in se and, more specifically, acts that are so wrong that any legal system is morally required to prohibit them. The fact that some legal system permits acts of torture, rape, murder, or enslavement is not a vindication of these acts but an indictment of that legal system. Insofar as a legal system fails to recognize and to realize the independently existing rights of human beings, it is widely thought to lose its authority, that is, its title to command and its power to create nonprudential reasons for its addressees to support it and to comply with its rules. Thus, even if the U.S. Supreme Court were to find that the executive did nothing wrong by delivering people suspected of terrorist activities to Syria for torture, for example, such finding would still leave open the pressing questions whether the Court interpreted existing law correctly and, if so, whether the renditions permitted by the law were or were not violations of the human right of the persons rendered.

11. Universal Declaration of Human Rights, G.A. Res. 217 (III)A, pmbl., U.N. Doc. A/RES.217(III) (Dec. 10, 1948). 
of human rights, but, on the contrary, asserting that all human beings have certain human rights regardless of whether these are recognized in their jurisdiction or indeed anywhere at all. Human rights are set forth in the law in a way that implies that these rights have an independent existence and thus existed before they were codified and would continue to exist even if governments were to withdraw their legal recognition.

Born of the horrendous abuse of the law in Nazi Germany, this selfrestraint of the law is a great advance in human civilization. Endorsing this advance just because governments have endorsed it would miss the essence of their endorsement. Governments have taken this step in a way that clearly recognizes that it is right independent of their endorsement. They have recognized that the Nazis, had they won the war, could not have abolished human rights (though they could, of course, have systematically violated them in their law and practice). The advance should be endorsed in this spirit. The legal texts in which governments formulate human rights and explicate their correlative duties do, of course, deserve close attention. But when studying these texts one should also understand that they are not, by their own self-conception, definitive. Whether there are human rights, what human rights there are, and what duties these human rights entail - these questions are not settled by the texts alone.

Because human rights law points beyond itself in this way, the question of what duties human rights entail does not boil down to the question of which such duties competent courts applying current law would recognize. Both Shue and the authors of General Comment 12 approach the question in this spirit and the remainder of this Article follows their example.

\section{From Non-Fulfillment to Violation}

What is the relationship between the non-fulfillment of a human right and its violation? In order to answer this question, we must differentiate the various kinds of causal pathways by which one human agent's conduct may affect the fulfillment of a person's human rights. Four distinct pathways are distinguished in General Comment 12. Reconstructing this distinction without the artificial limitation to states, one can say that human rights may give human agents four distinct kinds of duties: duties to respect human rights, duties to protect (secure access to the objects of) human rights, duties to provide (secure access to) the objects of human rights, and duties to facilitate human rights fulfillment. My discussion of these four duties will focus on cases where a breach of the duty counts as a human rights violation. This sentence suggests that some breaches of humanrights-correlative duties are not human rights violations. That this is so is illustrated by cases of uninvolved bystanders who can protect or provide at reasonable cost. They have a duty to do so but are not human rights violators if they fail. Consider a rich Swede in 1830, who could have bought slaves and set them free or could have sent money or food to starving people in India. Many will say that he ought to have done this and had a duty to do it. But few will say that, by doing nothing of this sort, he 
violated the human rights of those he failed to rescue. The latter judgment is widely rejected in part for the unsound reason that the number of those who needed rescuing far exceeded his capacity for rescue, which makes it unclear whose human rights his failure violated. ${ }^{12}$ The compelling reason why the language of violation seems inappropriate here is that the Swede was not responsible for, nor implicated in, the relevant human rights being unfulfilled - he is in a position to help the starving and the enslaved, but he himself played no role in their starvation or enslavement. ${ }^{13}$ Not every case of a human right being unfulfilled is a case of this right being violated. An unfulfilled human right manifests a human rights violation only if there are one or more human agents who are bringing about the un-fulfillment of the human right in question even while they could and should have known that their conduct would have this result.

The most straightforward human rights violations involve breaches of duties to respect, that is, duties "not to take any measures that result in preventing" a human being from having secure access to the object of a human right. As this negative formulation indicates, these are conceived as negative duties: duties that can be honored by remaining passive and can be breached only by taking action. So what actions should these duties forbid? They should forbid any action that is reasonably avoidable and foreseeably causes some human being to be prevented from enjoying secure access to the object of a human right. This formulation requires at least two clarifications. First, the expression "reasonably avoidable" may seem redundant: if the agent could and should foresee that the contemplated action would prevent a human being from having secure access to the object of a human right, then (one might think) the agent can and ought to avoid this effect. But there may be cases where refraining would allow the occurrence of massive harms that only the contemplated action can avert. And one might then formulate the duty so that it does not apply in such cases on the ground that the agent cannot reasonably avoid the relevant action. Second, the word "causes" should be read to include cases where the preventing is effected indirectly, as when a commander orders his soldiers to destroy a dam, thereby depriving peasants of the water they need to irrigate their crops. If the soldiers obey and famine results, they as well as their commanding officer have breached their duty to respect the human rights of the affected population. It may not be plausible, however, to count all such indirect cases as breaching a duty to respect. A military junta may try to blackmail a journalist not to publish her story about the

12. This supposed problem can be solved if we say that, by doing nothing, he violated the human rights of them all. This does not go against the ought-implies-can constraint provided we add that, by helping as much as he was morally required to do, he extinguished the claims on him even of those for whom he did nothing. This seems plausible to me: the defense "I cannot help all" as addressed to a person one can but does not help is a good defense if and only if one is actually giving to other persons as much help as one ought to give overall.

13. The Swede might have been implicated in, without being responsible for, the underfulfillment of human rights if he was a beneficiary of the wrongs that caused the enslavement or starvation (if, for example, he inherited his fortune from his father who profited from investments in the slave trade). 
junta's corruption by threatening that it will kill some of its political prisoners if she goes ahead. In such a case, it would be unconvincing to say that the journalist, if she publishes the story nonetheless (even while she can foresee that the junta will implement its threat) is breaching her duty to respect the political prisoners' human right to life. Here only the junta and its henchmen are human rights violators, the journalist is not (which is not to say that going ahead with the story is clearly the right decision in cases of this sort).

Duties to protect and duties to provide are similar in that they both are positive duties: duties that require active intervention in a situation and that cannot be discharged by remaining passive. These duties apply to agents like the earlier Swede, who was neither responsible for, nor implicated in, the human rights deficits he found himself in a position to diminish; and breaching duties of either kind does not then count as a human rights violation. The two positive duties are distinguished by reference to the type of threat that triggers them and by the mode of intervention they require. Duties to protect are understood as requiring human agents to take preventive action when the fulfillment of human rights is endangered by social threats: by other human agents who are, perhaps inadvertently, disposed to act in ways that render such access insecure. The duty requires that one render the objects of human rights secure by preventing either the potentially harmful actions or their potentially harmful effects. Duties to provide are understood as requiring a different response to social threats: not a blocking of the threat but a neutralizing of its harmful effects. Duties of the two kinds are complementary in that one becomes moot insofar as the other is discharged: if UN troops break the siege of a city and thereby restore its usual food supply, then the obligation to provide food to the city's population dissolves; and, conversely, if the UN provides food to the city's people, it staves off the human-rights-based obligation to break the siege of the city in order to protect its people from being separated from their food supplies. ${ }^{14}$

Duties to respond to natural disasters that threaten the fulfillment of human rights are generally classified as duties to provide. Exemplified in human rights documents (including General Comment 12), this is an unfortunate practice because it obscures the fact that, as in the case of social threats, the task can be discharged in two fundamentally different ways: by preventing the harm from reaching people or by assisting people in coping with it. The common label tends to draw attention to the latter approach;

14. In such cases of complementarity, it makes sense to choose the less costly option. In most cases, however, successful efforts to provide are inferior substitutes for successful efforts to protect. While the siege is going on, the residents of the city are unlikely to have secure access to the objects of their human rights, even if food is being airlifted by the UN. Similarly, providing medical supplies to people subject to military aggression can only reduce the human rights deficit, while deterring or blocking the aggression might avoid this deficit altogether. In some cases, the conceptual boundary between the two duties is unclear. Thus, if the rulers of a country are unable or unwilling to maintain an orderly police force that ensures citizens' physical security, and if UN troops then take on this function, these UN soldiers could be said to protect citizens from criminal violence or alternatively to provide the missing security. 
and nearly all international efforts to cope with natural disasters are indeed focused on assistance ex post rather than on (often more cost-effective) prevention ex ante. A good step toward correcting this irrational bias would be to break out duties to protect human beings from natural disasters as a separate category of human-rights-correlative duties.

Given that they are positive duties, duties to protect and to provide are largely irrelevant to the topic of human rights violations (as I have proposed to define them). Yet two further points should be made about them here. First, those who prevent effective conduct pursuant to a duty to protect or to provide typically breach a duty to respect and can then be labeled human rights violators. For example, those who ordered General Romeo Dallaire not to confiscate the weapons that the Interahamwe militias were assembling in Kigali, Rwanda, in preparation for the 1994 genocide were breaching their duty to respect human rights, provided they could and should have known that Dallaire had an essentially correct assessment of what these weapons were intended to be used for. ${ }^{15}$ By preventing the action Dallaire was about to undertake, they were actively intervening in the situation in a way that would foreseeably lead to the reasonably avoidable slaughter of hundreds of thousands of innocent people.

Second, even a failure to protect or provide can constitute a human rights violation in cases where the agent has assumed a special role that involves protecting or providing (secure access to) objects of human rights. For example, when a police officer remains passive when he sees a wild teenager beat up a homeless woman nearby, he is not merely breaching his duty to protect (as a civilian bystander might), but also his duty to respect human rights. He is breaching a negative duty: the duty not to assume an office and then fail to perform its associated tasks. This is analogous to the case of promising discussed above, where the duty not to break one's promises, although it is negative because it can be discharged by remaining passive, may nonetheless generate positive obligations (e.g., to return a book one had promised to return). One has the option of remaining passive, never to become a promisor, which brings one into easy compliance with the negative duty. But once one actively assumes the role of promisor, then one's duty not to break one's promise may require further action (if such was promised). Likewise with the roles of police officer, lifeguard, physician, and the like: one is violating human rights when one undertakes to occupy such a role and then fails to meet its requirements in a way that foreseeably and avoidably renders insecure the access others have to the objects of their relevant human rights. These points are unlikely to be controversial in cases where the role occupant's failure to take appropriate action to safeguard a human right breaches the requirements of his role as officially specified (perhaps in a legal document that he had signed when he took on the job). These points become more controversial when the role definitions are unjustly specified, for example, when role occupants are not legally required to - or even legally required not to -

15. See POGge, POLITICS As UsUAL, supra note 2, at 168-69. 
protect or assist people of a certain color, religion, or political persuasion. Is a "for whites only" lifeguard (like all other competent swimmers on the beach) breaching only a positive duty when he lets a black child drown, or is he in addition (unlike other competent swimmers) also breaching a negative duty to respect? It will be easier to think about this question after reflecting on duties to facilitate.

In explication of duties to facilitate, General Comment 12 prescribes that "the State must pro-actively engage in activities intended to strengthen people's access to and utilization of resources and means to ensure their livelihood, including food security."16 Transcending the respect-protectfulfill triad, the authors of General Comment 12 clearly conceived of duties to facilitate as distinct from duties to provide and also as important enough to be broken out as a separate category. Why? Posting lifeguards and instructing them to rescue all swimmers in trouble, maintaining homeless shelters that also serve nutritious meals, underwriting basic medical services for poor people - all such state activities could easily be classed as duties to provide. The introduction of a new category of duties to facilitate is best explained as reflecting the recognition that the extent to which human rights are fulfilled depends on the totality of background conditions prevailing in a society. Some of these background conditions are subject to human modification only in minor ways or very slowly or not at all. But the effect of even these conditions is not preordained but rather shaped by other background conditions that are very much under human control. Of greatest importance here is the way the state structures and organizes a society. For example, the structure of a society's economy profoundly affects the distribution of income and wealth; the way its criminal justice system is organized greatly influences what dangers citizens face from criminal activities; and the design of its education system makes a large difference to the opportunities various groups of citizens have to participate effectively in the political process and to defend their legal rights. Badly organized societies pose massive threats to the objects of their members' human rights. In response to these threats, one can impress upon the governing elites, and perhaps upon other citizens as well, the importance of their duties to respect, protect, and provide. But such appeals are of limited usefulness in a society in which members of the elite can embezzle with impunity or in which citizens who work to protect the rights of fellow citizens are persecuted as disloyal or treasonous and subjected to arbitrary beatings and detentions by organizations whose status and legal basis remains shrouded in secrecy. What such a society needs is structural reform: reorganization. ${ }^{17}$

16. General Comment 12 , supra note 8 .

17. General Comment 12 could surely have stated this point more clearly - but then, some lack of clarity is perhaps understandable in a document submitted to states (or States, as they like to be called) for their approval. In the text, I am offering what I see as the most charitable interpretation of what the authors had in mind when they added this category. But nothing is lost for the argument of this piece if this conjecture about their thoughts turns out to be incorrect. What matters for the purpose at hand is the plausibility of the substantive point 
Duties to facilitate constitute then a crucial addition which highlights the vital importance that the design of institutional arrangements has for the fulfillment of human rights. This importance is overlooked on a purely interactional understanding of human rights fulfillment which can, somewhat simplistically, be put as follows: 1) Human rights would be universally fulfilled if all human agents complied with their duties to respect; 2) regrettably, some human agents do not do this and their disposition to violate human rights triggers duties to protect; 3) unfortunately, the willingness or ability of human agents to comply with their duties to protect is insufficient to deter and prevent all breaches of duties to respect; 4) this fact, along with the occurrence of natural disasters which may also undermine human rights fulfillment, triggers duties to provide, that is, duties to help people overcome impediments that obstruct or render insecure their access to the objects of their human rights. ${ }^{18}$

The purely interactional analysis of human rights deficits must then be complemented by an institutional analysis which traces such deficits back not to wrongful conduct of individual and collective human agents, but to injustice in the design of social institutions: in the rules and procedures, roles and agencies that structure and organize societies and other social systems. The two kinds of analysis are often complementary. Thus, each instance of slavery is the responsibility of one or more human agents who (typically with violence or intimidation) subject a human being to their domination; and the persistence of slavery on a massive scale is the responsibility of unjust social institutions such as (in the bad old days) the legal protection of property rights in persons and (in the supposedly enlightened present) the massive reproduction of life-threatening poverty and the effective non-recognition by national criminal justice systems of the human rights of poor foreigners from countries outside the "First World."19 Similarly, each marital rape is a moral crime committed by a husband; and persistent high prevalence of marital rape exhibits institutional injustice in legislation as well as in the training of police and judicial officers.

attributed to the authors rather than the plausibility of this attribution. General Comment 12, supra note 8 .

18. Such an account of "waves of duties" is suggested in Jeremy Waldron, Rights in Conflict, 99 ETHICS 503, 510 (1989). It is then picked up by Henry Shue in the 1996 Afterword to his BASIC RIGHTS, supra note 6, at 156. But both authors are aware of the importance for human rights fulfillment of attention to the design and reform of institutional arrangements - as cited above, Shue lists a category of duties to protect from deprivation by designing institutions that avoid the creation of strong incentives to violate duties to avoid depriving. For further discussion, see also Thomas Pogge, Shue on Rights and Duties, in GLOBAL BASIC RighTS 113 (Charles Beitz \& Robert Goodin eds., 2009); Kieran Donaghue, Human Rights, Development INGOs and Priorities for Action, in ETHICAL QUESTIONS AND INTERNATIONAL NGOS: AN EXCHANGE BETWEEN PHILOSOPHERS AND NGOS 39 (Keith Horton \& Chris Roche eds., 2010).

19. Though precise figures are not available, the number of slaves today is commonly estimated to be around 27 million. "There are more slaves today than were seized from Africa in four centuries of the trans-Atlantic slave trade. The modern commerce in humans rivals illegal drug trafficking in its global reach - and in the destruction of lives." Andrew Cockburn, 21st Century Slaves, NAT'L GEOGRAPHIC (Sept. 2003), http://ngm.nationalgeographic.com/ngm/0309/feature1/. 
Contrasting with these cases of complementarity, there are also many cases where institutional analysis reaches beyond interactional analysis and thus enables intelligent responses to human rights deficits that, on a purely interactional analysis, remain elusive. Poverty is an example of this. When people are too poor to meet securely their basic needs, then there are sometimes specific others who have caused this poverty. Hunger may be due to an increase in local food prices caused by a large local landowner switching his production from foodstuffs to ethanol - or it may be due to corrupt politicians throwing poor peasants off their land to make room for a casino or shopping center. Obvious failures to fulfill duties to provide may also be in play. But most typically hunger is systemic: arising in the context of some economic order from the effects of the conduct of many market participants who cannot foresee how their decisions, together with those of many others, will affect specific individuals or even the overall incidence of severe poverty. While it is straightforward what husbands must not do in order to respect their wives' human right to physical security, it is not straightforward and may in fact be unknowable what market participants must not do to respect others' human right to an adequate standard of living. This human right can best be realized through suitable socioeconomic institutions, and it was in fact appropriate institutional design that led to the realization of this right in the countries where it is realized. ${ }^{20}$

While institutional analysis with a moral purpose goes back a long way, ${ }^{21}$ its recent exemplar is John Rawls's great work A Theory of Justice.22 While focusing on social institutions and more specifically on the basic structure of a national society existing under modern conditions, this work's normative message is addressed to the citizens of such a national society, offering to explicate for them their "natural duty of justice" which, Rawls believes, "requires us to support and to comply with just institutions that exist and apply to us . . . [and] to further just arrangements not yet established." ${ }^{23}$ His argument for such a natural duty of justice is important in highlighting how the members of a society can institutionally address socio-economic deprivations and inequality even when it is very difficult or impossible to effectively address them through individual efforts toward protection or provision. But Rawls's formulation of the argument also involves (what I regard as) a serious and highly influential flaw, namely the unthinking presupposition that citizens' duties with regard to the social institutions they are involved in designing or upholding are one and all positive duties. In an elaborate mapping exercise, Rawls explicitly

20. The word "realize" is used in the sense of "fulfill for all." A human right is fully realized in some jurisdiction, or in the world at large, just in case all human beings in this jurisdiction, or in the world, have secure access to its object.

21. For an important milestone in the Anglophone discussion see JEREMY BENTHAM, AN InTRODUCTION TO THE PRINCIPLES OF MORALS AND LEGISLATION (J.H. Burns \& H.L.A. Hart eds., Clarendon Press 1996) (1789).

22. JOHN RAWLS, A THEORY OF JUSTICE (1971).

23. Id. at 115; see also id., at 246, 334 . 
characterizes our natural duties in regard to institutional design as positive duties, likening them to other positive duties such as those of mutual aid and mutual respect, while contrasting them with negative duties such as those not to injure and not to harm the innocent. ${ }^{24}$ If citizens' duty to look after the justice of their shared social institutions is a positive one, then it is of lesser import - on the widely shared assumption, reiterated by Rawls, that "when the distinction is clear, negative duties have more weight than positive ones." 25

Political thinkers and jurists writing after Rawls have unquestioningly accepted his view that the responsibility for the justice of social institutions is a positive responsibility, without recognizing that the adoption and incorporation of this view is a contestable decision of some consequence. So this responsibility is now everywhere cast in purely positive terms. General Comment 12 demands that "the State must pro-actively engage in activities intended to strengthen people's access to and utilization of resources and means to ensure their livelihood, including food security." 26 And Henry Shue's complex formulation also turns out to be a positive one: casting our relevant responsibility as one to design institutions that avoid the creation of strong incentives to violate human rights - rather than one not to design or uphold social institutions that create strong incentives to violate human rights.

The problem here is not with the scope of the duty: Rawls and his successors are not failing to call on citizens to do something that they ought to be doing. The problem is with the character of the duty and the weight it is assigned. On the now conventional view, a society's social institutions have important effects on the lives of its members, and the government and the citizenry therefore ought to improve these institutions so as to promote their justice (Rawls) or rights fulfillment (Shue). But this positive duty to help improve the justice of social institutions sustains no principled differentiation between the social institutions of one's own society and those of any other society. A Turk's obligation to promote the justice of Turkey's social institutions is on a par with her obligation to promote the justice of Paraguay's social institutions. To be sure, it will often be true that citizens will be more effective when they focus their time and resources on improving the institutions of their own society - just as they will typically be more effective when they discharge their duty to aid the needy in their own country rather than abroad. Many would add to this that one's positive duties are more stringent toward people who are culturally and geographically closer to oneself, with the implication that, even when costeffectiveness is equal, one has a weightier moral reason to help a compatriot than a distant stranger and weightier moral reason also to promote the institutional justice of one's own society (which would benefit some of one's compatriots) than to promote the institutional justice of some

\footnotetext{
24. Id. at 109 .

25. Id. at 114 .

26. General Comment 12 , supra note 8.
} 
distant society (which would benefit faraway strangers). Giving full weight to these two considerations, the conventional view can then reaffirm the common creed that - even if it is generally cheaper to promote the justice of Paraguay's social institutions than Turkey's - Turks should normally focus their efforts to promote social justice upon the social institutions of Turkey rather than those of Paraguay.

This way of thinking can be criticized, but my interest here is in complementing it. The point can be introduced with a dramatic analogy. Imagine a driver who encounters a badly hurt child by the side of the road. Being a local, the driver knows the area well and knows, in particular, how to get the boy quickly to the nearest emergency room. She can see that the boy is bleeding profusely, so that her failure to drive him there may well cost him his life. Having exchanged a few words with the boy, she also knows that he lives nearby and thus is geographically and culturally close to herself. Given all these facts, her duty to aid human beings in need generates a stringent obligation to drive the boy to the hospital as quickly as she safely can.

Let us now add another detail to the story, namely that it was the driver herself who caused the boy's condition: engrossed in an intense cell phone conversation, she hit the boy after seeing him too late and then lost more precious time getting her right hand back on the steering wheel. This new information does not affect the initial conclusion that she has a weighty obligation to assist by quickly driving the boy to the hospital. But this conclusion is now overshadowed by an even weightier moral reason: if what she does in the next few minutes does not succeed in getting the boy's life saved, then she will have killed (rather than merely injured) him. Her negative duty not to kill thus generates another, even more stringent obligation of identical content: she must drive the boy to the hospital as fast as she safely can.

The key point of the analogy is then that the citizens of a society generally have two obligations to work toward making its social institutions more just. One of these derives from their quite general positive duty to promote the justice of social institutions for the sake of safeguarding the rights and needs of human beings anywhere. The other obligation derives from their negative duty not to collaborate in designing or imposing unjust social institutions upon other human beings. In regard to a citizen's home society, the content of these two obligations is essentially the same. But they differ in stringency. Other things equal, it is worse to let an injustice persist if one is complicit in it than if one is merely an uninvolved bystander. If the injustice manifests itself in human rights deficits, then one is a human rights violator in the first case but not in the second. And this provides an additional, stronger, and non-instrumental rationale for why typical Turkish citizens should focus their political reform efforts on Turkey in preference to Paraguay. If Turkey is so organized that some human rights avoidably remain widely unfulfilled among the Kurdish minority, then such Turkish citizens are participants in a human rights violation. By contrast, they are not similarly implicated when 
Paraguay is so organized that some human rights avoidably remain widely unfulfilled among Paraguay's indigenous people. ${ }^{27}$

General Comment 12 is right to recognize that the fulfillment of human rights is greatly affected by social institutions. It is right to acknowledge the important duties human agents have in regard to the design of social institutions by breaking out duties to facilitate as a separate category. To this must be added, however, another separate category of duties not to collaborate in the design or imposition of social institutions that foreseeably and avoidably cause human rights to be unfulfilled. These duties are close to duties to facilitate in regard to the focus on social institutions and the related purpose of reducing human rights deficits through institutional reform. They are close to duties to respect in regard to their essentially negative character: it is only by breaching duties to respect or duties not to collaborate that one can become a violator of human rights.

\section{Human Rights Violation as a Relational Predicate and the Duty to Facilitate}

As the foregoing discussion brings out, the concept of a human rights violation is a relational predicate, involving specific responsibilities by particular human agents in regard to unfulfilled human rights of persons. When many among Paraguay's indigenous population are unable to attain an adequate standard of living, then this may indicate a human rights violation on the part of Paraguay's political and economic elite insofar as they are collaborating in the imposition of unjust social institutions in Paraguay and also insofar as they are abusing their indigenous servants or employees. The same human rights deficit indicates no human rights violation but merely a breach of positive duty on the part of an affluent citizen of Turkey who - even if he leaves undone things he could easily do toward protecting, providing, or facilitating secure access by indigenous Paraguayans to the objects of their human rights - is not involved in abusing them or in designing or imposing upon them unjust social institutions. And the same human rights deficit may not indicate any breach of duty on the part of impoverished citizens of Sierra Leone or indeed of most of Paraguay's indigenous people themselves - the former are simply unable to improve the living conditions of indigenous Paraguayans and the latter cannot reasonably be said to be morally required to undertake political action toward realizing their own and each other's human rights when such action would be excessively risky and costly for them.

Two central points have here been made about the notion of a human rights violation. One is a call to resist the tendency to deflate the term "human rights violation" by using it in a broad sense so that it covers all

27. I am here leaving aside the possibility that Turkish citizens may be implicated, through their government, in the design or imposition of unjust supranational institutional arrangements that contribute to the human rights deficit in Paraguay. This possibility will be extensively explored in Part III. 
cases, or all avoidable cases, of unfulfilled human rights. If possible, the expression should be saved from the political preachers and media windbags ever in search of stronger expressions to show that they care more than the rest. Human rights violations are not tragic events, like the destruction of a town by a meteorite, nor even culpable failures to give enough aid or protection. Human rights violations are crimes actively committed by particular human agents who should be identified and then be persuaded to change their ways or else stopped.

The other point is that human rights violations come in two varieties, one of which has (unsurprisingly) been overlooked. There is the interactional variety, where individual or collective human agents do things that, as they intend, foresee, or should foresee, will avoidably deprive human beings of secure access to the objects of their human rights. And there is the institutional variety, where human agents design and impose institutional arrangements that, as they intend, foresee, or should foresee, will avoidably deprive human beings of secure access to their human rights. ${ }^{28}$ That the latter variety is overlooked among those who enjoy the privilege of theorizing about justice and human rights is related to the fact that its recognition would bring into full view a large crime against

28. In my book World Poverty and Human Rights: Cosmopolitan Responsibilities and Reforms, I developed an institutional understanding of human rights but regrettably overstated my case. Crucial for my argument was the idea that agents can violate human rights by contributing to the design or imposition of institutional arrangements that foreseeably cause avoidable human rights deficits. This idea is essential for a plausible assignment of responsibility for many human rights deficits in the modern era, which are among the largest of human history. THOMAS POGgE, WORLD POVERTY AND HUMAN RIGHTS: COSMOPOLITAN RESPONSIBILITIES AND REFORMS, ch. 2 (2002). But I did not need, and should not have argued for, the rejection of the interactional understanding of human rights. There was no need to deny that agents can violate human rights in ways other than through their contributions to designing or upholding institutional arrangements. I have since recognized this mistake and apologized for it in my response to Rowan Cruft in a symposium on the book, and so can simply reproduce this apology here (from Pogge, supra note 3, at 65-66):

At the core of my book is the view that the human rights of others impose upon us a negative duty "not to cooperate in the imposition of a coercive institutional order that avoidably leaves human rights unfulfilled without making reasonable efforts to aid its victims and to promote institutional reform" (p. 170; see also pp. 70, 144 [WORLD POVERTY AND HUMAN RIGHTS]). The human rights of others may impose further duties upon us, positive or negative ones, but my argument is meant to avoid any commitment, one way or the other, with regard to such duties.

It goes against this ecumenical spirit, and therefore was a mistake of mine, to have written: "In proposing this institutional understanding, I reject its interactional alternatives: I deny, for instance, that postulating that persons have a human right to $X$ is tantamount to asserting that some or all individual and collective human agents have a moral duty - in addition to any legal duties they may have in their society - not to deny $X$ to others or to deprive them of $X^{\prime \prime}$ (p. 65 [WORLD POVERTY AND HUMAN RIGHTS]). This mistake may have helped to mislead Cruft, and I apologize for it. I stand by my defense of an institutional understanding of human rights. But I do not want to deny (or assert) that human rights also impose positive or negative interactional duties. Taking a position on this matter is unnecessary for the book's argument and hence best avoided.

An expanded and corrected second edition of WORLD POVERTY AND HUMAN RIGHTS was published in 2008. 
humanity that is now going on and in which these theorists and their readers are involved. This crime is the design and imposition of unjust supranational institutional arrangements that foreseeably and avoidably cause at least half of all severe poverty which in turn is by far the greatest contributor to the current global human rights deficit.

Consciously or unconsciously, normative theorists obscure this crime in two main ways. The traditional approach is to present national borders as moral watersheds. Each state is responsible for the fulfillment of human rights in its territory, and the responsibility of foreign actors is limited to (at most) a positive duty of assistance. ${ }^{29}$

An emerging alternative to the traditional approach might be called the contemporary approach. Its emergence and success owes much to the phenomenon of globalization. Transforming the traditional realm of international relations, one central component of globalization has been the creation of an increasingly dense and influential global system of rules along with a proliferating set of new international, supranational, and multinational actors. These transnational rules and actors reach deep into the domestic life of (especially the poorer) national societies by shaping and regulating not only the ever-growing share of interactions that traverse national borders, but increasingly also purely domestic interactions. In view of the evidently profound effects that these transnational rules and actors have on the lives of human beings worldwide, it has become ever more palpably untenable to claim for them a morality-free zone in which the concept of justice has no application. ${ }^{30}$ So the contemporary approach does the next best thing by acknowledging a duty to facilitate the realization of human rights. In addition to positive duties to contribute to the remedial protection and provision of missing objects of human rights, agents are now assigned the additional duty to promote the realization of human rights through the improvement of institutional arrangements. As with the other two positive duties, this new duty is understood as "imperfect," leaving its bearers nearly unlimited discretion over what and how much they will do. From there it is only a small step to the position the United States set forth in an "Interpretative Statement" it issued in regard to the Rome Declaration on World Food Security: "the attainment of any 'right to food' or 'fundamental right to be free from hunger' is a goal or aspiration to be realized progressively that does not give rise to any international obligations." 31

The contemporary approach represents a step forward in its acknowledgement that the proliferating supranational institutional architecture is neither causally nor morally neutral. But by assigning us, in regard to these supranational institutional arrangements, an open-ended

29. Rawls exemplified this traditional view with the recognition of such a positive duty of assistance. See JOHN RAWLS, THE LAW OF PEOPLES 37, 106-19 (1999).

30. This was done done, in the wake of Rawls, by Thomas Nagel. Thomas Nagel, The Problem of Global Justice, 33 PHIL. \& PUB. AfF. No. 2, 113 (2005).

31. World Food Summit, Nov. 13-17, 1996, Report of the World Food Summit, Annex II, U.N. Doc. WFS 96/REP, available at http://www.fao.org/wfs/. 
task of improvement, the contemporary approach presents this responsibility as exclusively positive and thereby reinforces a central doctrine of the traditional approach: the only way foreigners can violate human rights is through violent cross-border intervention. Though recognizing that our design of supranational institutions has important effects on human rights fulfillment worldwide, the contemporary approach still hides the possibility that this supranational order is fundamentally unjust. This possibility is important. For if the existing system of supranational institutional arrangements is fundamentally unjust, then "progressive improvement" ceases to be a sufficient response. There was a time when people talked about the improvement of slavery - about legislative changes that might facilitate more tolerable living conditions by curbing rapes, beatings, and splitting of families, by reducing backbreaking labor, and by guaranteeing minimally adequate food, shelter, and leisure time. But as slavery came to be recognized as fundamentally unjust, the only adequate response to it was abolition. An institutional injustice is not something to be gradually ameliorated at one's leisure. It is to be eliminated through institutional reforms with all deliberate speed pursuant to a negative duty (on the part of the citizens of the antebellum United States and on the part of us now) not to impose unjust social institutions and, in particular, ones that foreseeably give rise to a reasonably avoidable human rights deficit. In this regard, severe poverty and slavery are on a par: when social institutions avoiding these deprivations are reasonably possible, then the imposition of social institutions that perpetuate these deprivations constitutes a violation of the human rights of those who are enslaved or impoverished.

\section{We Are Violating the Human Rights of the World's PoOR: THE EMPIRICAL EVIDENCE}

On the background of the understanding of human rights violations presented in Part II, we may now turn to the question of whether we are indeed violating the human rights of the world's poor. The answer is yes. There exists a supranational institutional regime that foreseeably produces massive and reasonably avoidable human rights deficits. By collaboratively imposing this severely unjust institutional scheme, we are violating the human rights of the world's poor.

Section II.D has shown how normative theorists sustain this injustice by allowing no space in their catalogues of duties for a negative duty not to collaborate (that is, immediately to stop collaborating) in the imposition of unjust institutional arrangements. This Part will show how empirical theorists sustain the injustice by arguing that globalization is good for the poor (Section A) and that the causes of the poverty that remains today are domestic to the societies in which it persists (Section B). The Part concludes with some thoughts about what we ought to do in light of the actual causes of global poverty (Section C).

It may be useful to precede the discussion with a brief reminder of the 
state of human rights fulfillment today. About half of all human beings live in severe poverty and about a quarter live in extreme or life-threatening poverty. They appear in statistics such as the following: 925 million people are chronically undernourished, 32884 million lack access to improved drinking water, ${ }^{33} 2.5$ billion lack access to improved sanitation, ${ }^{34}$ and almost 2 billion lack regular access to essential medicines. ${ }^{35}$ Over 1 billion lack adequate shelter, ${ }^{36} 1.6$ billion lack electricity, ${ }^{37} 796$ million adults are illiterate, $^{38}$ and 215 million children are child laborers. ${ }^{39}$ About one third of all human deaths, 18 million each year, are due to poverty-related causes. ${ }^{40}$

\section{A. Is Globalization Good for the Poor?}

One way of disputing the claim that we are violating the human rights of the poor is by arguing that, because the percentage of very poor people has been declining (the first Millennium Development Goal, MDG-1, is phrased in these terms), globalization and the supranational institutional arrangements it has brought must be good for the poor. This argument employs an invalid inference. The relevant standard is not whether the lot of the poor has improved in the past quarter century of globalization, but rather whether there was not some knowably feasible alternative path of globalization, evolving some alternative scheme of supranational institutions, which would have led to a much smaller human rights deficit at the end of that period. If there is some such feasible alternative scheme, then we are violating the human rights of the poor by imposing upon them the current institutional arrangements. By analogy, suppose someone denied that the institutional order authorizing and enforcing black slavery in the United States in 1845 violated the human rights of slaves by pointing out that the proportion of slaves within the U.S. population (or even the absolute number of slaves) had been shrinking, that the nutritional situation of slaves had steadily improved, and that brutal treatment, such

32. 925 Million in Chronic Hunger Worldwide, U.N. FOOD AND AGRIC. ORG. (Sept. 13, 2010), http://www.fao.org/news/story/jp/item/45210/icate/.

33. New UNICEF Study Shows MDGs for Children Can Be Reached Faster with Focus on Most Disadvantaged, UNICEF (Sept. 7, 2010), www.unicef.org/media/media_55913.html.

34. What We Do: Water, Sanitation and Hygiene, UNICEF, http://www.unicef.org/wash/ (last modified July 6, 2010).

35. World Health Org. [WHO], WHO Medicines Strategy: Countries at the Core-2004-2007, at 3, WHO Doc. WHO/EDM/2004.5 (2004), available at http://apps.who.int/ medicinedocs/pdf/s5416e/s5416e.pdf.

36. U.N. Human Settlements Programme, The Challenge of Slums: Global Report on Human Settlements 2003, at XXV, U.N. Doc HS/686/03E (2003), available at http:/ / www.unhabitat.org/pmss/listItemDetails.aspx?publicationID $=1156$.

37. Our Work: Urban Energy, U.N. HABITAT, http://www.unhabitat.org/content.asp?cid $=2884 \&$ catid $=356 \&$ typeid $=24 \&$ subMenuId $=0$ (last visited Apr. 4, 2011).

38. Literacy Topic, UNESCO INST. FOR STATISTICS, http://www.uis.unesco.org/ev _en.php?ID=6401_201\&ID2=DO_TOPIC (last modified Mar. 29, 2011).

39. Topics: Child Labour, INT'L LABOUR ORG., http://www.ilo.org/global/ topics/childlabour/lang--en/index.htm (last visited Apr. 4, 2011).

40. World Health ORganization, Global Burden of Disease: 2004 Update, 54-59, tbl.A1 (2008). 
as rape, whipping, and splitting of families, had also been in decline. Let us stipulate, for the sake of the argument that the worst hardships of slavery were really continuously declining in these ways. Does this fact weaken, in any way, the claim that the institution of slavery violated the human rights of slaves? If the answer is no, then the mere fact that the worst hardships of poverty have been declining throughout the globalization period cannot refute the claim that the imposition of the current global institutional order violates their human rights. The relevant question is not whether and how much the global human rights deficit has been declining but rather whether and how much the design of the supranational institutional arrangements we impose contributes to the human rights deficit that remains. ${ }^{41}$

Bearing this commonsense standard in mind, let us observe how various segments of the human population have fared during the globalization period. ${ }^{42}$

\begin{tabular}{|l|l|l|l|l|}
\hline $\begin{array}{l}\text { Segment of } \\
\text { World } \\
\text { Population }\end{array}$ & $\begin{array}{l}\text { Share of } \\
\text { Global } \\
\text { Household } \\
\text { Income 1988 }\end{array}$ & $\begin{array}{l}\text { Share of } \\
\text { Global } \\
\text { Household } \\
\text { Income 2005 }\end{array}$ & $\begin{array}{l}\text { Absolute } \\
\text { Change in } \\
\text { Income } \\
\text { Share }\end{array}$ & $\begin{array}{l}\text { Relative } \\
\text { Change in } \\
\text { Income } \\
\text { Share }\end{array}$ \\
\hline Richest 5\% & 42.87 & 46.36 & +3.49 & $+8.1 \%$ \\
\hline Next 5\% & 21.80 & 22.18 & +0.38 & $+1.7 \%$ \\
\hline Next 15\% & 24.83 & 21.80 & -3.03 & $-12.2 \%$ \\
\hline $\begin{array}{l}\text { Second } \\
\text { Quarter }\end{array}$ & 6.97 & 6.74 & -0.23 & $-3.3 \%$ \\
\hline $\begin{array}{l}\text { Third } \\
\text { Quarter }\end{array}$ & 2.37 & 2.14 & -0.23 & $-9.7 \%$ \\
\hline $\begin{array}{l}\text { Poorest } \\
\text { Quarter }\end{array}$ & 1.16 & 0.78 & -0.38 & $-32.8 \%$ \\
\hline
\end{tabular}

As the table shows, the top five percent of the global income distribution has gained substantially over the globalization period, while the poorest eighty percent have lost ground. With the losses most severe in the poorest quarter, there has been dramatic polarization: in a mere seventeen years, the ratio between the average income in the top five

41. This paragraph draws on my reply to Matthias Risse in Pogge, Severe Poverty as a Violation of Negative Duties, supra note 3, at 55-58. For a more extensive discussion of baselines for assessing institutional harm, see Thomas Pogge, Severe Poverty as a Human Rights Violation, in FREEDOM FROM POVERTY AS A HUMAN RIGHT: WHO OWES WHAT TO THE VERY POOR? 11, 1154 (Thomas Pogge ed., 2007). As I will show in a moment, it is questionable whether what I stipulated in this paragraph is actually true, namely that the worst hardships of poverty have been declining throughout the globalization period. See infra note 44 .

42. These data were kindly supplied by Branko Milanovic of the World Bank in a personal e-mail communication. See Email from Branko Milanovic, supra note 2. 
percent and that in the poorest quarter has skyrocketed from 185 to 297. The table also shows that, surprisingly, the world poverty problem - so unimaginably large in human terms - is tiny in economic terms. In 2005, the shortfall of the world's poor from an adequate standard of living was about 2 percent of global household income or 1.2 percent of world income (the sum of all gross national incomes). ${ }^{43}$ This global poverty gap could have been filled almost twice over, just from the gain in the share of the richest ventile (one twentieth) during the 1988-2005 period. Given these facts, it would be very hard indeed to make a good case for the claim that the massive poverty persisting today was not reasonably avoidable.

With the poorest quarter losing one third of its already absurdly small share of global household income, it is not surprising that very large numbers of human beings continue to subsist in extreme poverty, well below an adequate standard of living. The most credible figures we have on this front are the numbers of undernourished people as provided by the UN Food and Agriculture Organization. ${ }^{4}$

\begin{tabular}{|l|c|c|}
\hline Period & $\begin{array}{l}\text { Undernourished Persons } \\
\text { in Millions }\end{array}$ & $\begin{array}{l}\text { Undernourished Persons as a } \\
\text { Percentage of World Population }\end{array}$ \\
\hline $1969-1971$ & 878 & 26 \\
\hline $1979-1981$ & 853 & 21 \\
\hline $1990-1992$ & 843 & 16 \\
\hline $1995-1997$ & 788 & 14 \\
\hline $2000-2002$ & 833 & 14 \\
\hline $2005-2007$ & 848 & 13 \\
\hline 2008 & 963 & 14 \\
\hline 2009 & 1023 & 15 \\
\hline 2010 & 925 & 14 \\
\hline
\end{tabular}

What can we conclude from these data in regard to our central

43. This accords roughly with the World Bank's PPP-based tally which counted 3,085 million people as living in severe poverty in 2005 and estimated their collective shortfall - the global poverty gap - at $1.13 \%$ of world income. See POLITICS AS USUAL, supra note 2, at 69.

44. Data mostly from WOrLd FoOd PROGRAM AND FoOd AND AGric. ORG., THE STATE OF FOOD INSECURITY IN THE WORLD 2010: ADDRESSING FOOD INSECURITY IN PROTRACTED CRISES (2010), summarized at Hunger, FOOD \& AGRIC. ORG. OF THE UNITED NATIONS, www.fao.org/hunger/en/ (last visited Feb. 22, 2011), see also supra note 32. Number of undernourished in 2008 from FAO and Emergencies, FOOD \& AGRIC. ORG. OF THE UNITED NATIONS, www.fao.org/emergencies/tce-home/news/emergency-news/emergency-detail/ 0/item/8894/icode/en/ (last visited Feb. 22, 2011). Percentages for 2008-2010 are calculated by using figures from HUMAN POPULATION CLOCK, http:/ galen.metapath.org/popclk.html (last visited Feb. 22, 2011). Counting those living below \$1.25 per person per day at 2005 purchasing power parities, the World Bank produces a much prettier extreme poverty trend. But its calculations depend on several dubious methodological decisions including the use of inappropriate general household consumption PPPs. For extended discussion, see POLITICS AS USUAL, supra note 2 , ch. 4 . 
empirical question of whether a feasible alternative design of supranational institutional arrangements could have led to a smaller human rights deficit? While it is certainly possible that there was no such feasible alternative, it is highly unlikely given the data. For the denial of the possibility of such an alternative would amount to the wildly implausible claim that there was no feasible alternative institutional path of globalization that would have avoided the catastrophic losses in the income share of the poor while still achieving a reasonable rate of global economic growth. ${ }^{45}$

The implausibility of this claim becomes even more clear as we reflect on the strongly antidemocratic and pro-wealthy path that globalization has taken. Globalization involves the emergence of complex and ever more comprehensive and influential bodies of supranational law and regulations that increasingly pre-empt, constrain, and shape national legislation. Such supranational rules are not formulated through the kind of transparent, democratic procedures that characterize national law-making in the countries that have reached a basic level of domestic justice. Rather, supranational rules largely emerge through intergovernmental negotiations from which the general public and even the majority of weaker governments are effectively excluded. Only an unusually small number of 'players' can exert real influence over supranational rule-making: powerful organizations, prominently including large multinational corporations and banks, as well as very rich individuals and their associations and the ruling "elites" of the most powerful developing countries. These richest and most powerful agents are best positioned to engage in cost-effective lobbying. They can reap huge gains from favorable supranational rules and therefore can afford to spend great sums acquiring the necessary expertise, forming alliances with one another, and lobbying the stronger governments (G7, G8, and G20) that dominate supranational rule-making. Ordinary citizens, by contrast, typically find it prohibitively costly to acquire the necessary expertise and to form alliances that are large enough to rival corporate influence. In the absence of global democratic institutions, globalization sidelines the vast majority of human beings, who have no way of influencing the formulation and application of supranational rules, while greatly enhancing the rule-shaping powers of a tiny minority of those who are already the richest and most powerful. (Many of them foresaw this, of course, and were for this reason among the strongest supporters of the ongoing globalization push.) Their interests are diverse, and so they are competing and bargaining with one another - each seeking to shape and reshape supranational rules to be as favorable as possible to itself. There are winners and losers in these contests, some elite players fail in their efforts to shape in their favor the rules that stand to impact them the most. Yet, the rules do get captured by some elite players and, as a group, they consequently grow their share of global wealth and expand their advantage over the rest of humankind. This, in turn, further increases their capacity to

45. For a more extensive discussion, see Thomas Pogge, Responses to the Critics, in THOMAS POGGE AND HIS CRITICS 175, 175-191 (Alison Jaggar ed., 2010). 
influence the design and application of the rules in their own favor and, unintentionally but no less inexorably, keeps the poorer half of humankind in dire poverty.

Therefore it is not surprising that the institutional design shift upward, from the national to the supranational level, is further marginalizing humanity's poorer majority, who have no way of influencing supranational negotiations, and is further increasing the absolute and relative wealth and power of a tiny minority at the top, who can monopolize such influence. The rapid global polarization of the last 20 years is a foreseeable effect of a highly undemocratic path of globalization and the regulatory-capture opportunities it provides.

\section{B. Are the Causes of the Persistence of Poverty Purely Domestic?}

Empirical theorists provide a second line of defense of the status quo by arguing that the causes of the persistence of poverty are domestic to the societies in which poverty persists. The observed polarization is not one phenomenon, driven by supranational institutional arrangements, but rather two phenomena: good progress in well-organized Western countries, which maintain high levels of social justice and decent rates of economic growth, and mixed progress in many other countries, which pay little attention to social justice and whose economic growth is often held back by a range of local natural, cultural, or political impediments. Two sets of empirical findings are adduced as evidence for this picture. One is that the overall gap between affluent and developing countries is no longer growing, as China and India, in particular, have been maintaining longterm rates of economic growth that are considerably above those of Europe, North America, and Japan. ${ }^{46}$ This is taken to show that supranational rules are not biased against poor countries and that the main driver of polarization today is rising intra-national inequality which is under domestic control and each country's own responsibility.

In response, one might point out that, over the recent globalization period, only about one quarter of developing countries, and only about a tenth of the poorest developing countries, had growth in GDP per capita that exceeded that of the high-income countries as a group. ${ }^{47}$ But the more important point is that the increase of intra-national economic inequality in nearly all countries is no longer under easy domestic control but rather driven by the increasingly important role that supranational rules play in constraining and shaping national legislation and in governing domestic markets for goods, services, labor, and investments.

The influence of supranational rules is in some cases direct and immediate and in other cases mediated through competition. As an example of a direct and immediate influence, consider an important part of

46. See World BAnK, World Development Report 2010: Development AND Climate CHANGE 378-79 (2010).

47. WORLd RES. InSTITUTE, ECONOMICS, BUSINESS, AND THE ENVIRONMENT DATABASE, http:/ / earthtrends.wri.org/searchable_db/index.php?theme=5 (last visited Apr. 4, 2011). 
the World Trade Organization (WTO) regime, namely the 1994 TradeRelated Aspects of Intellectual Property Rights (TRIPS) Agreement which requires WTO members to institute national intellectual property regimes that award and enforce product patents of at least twenty-year duration on new medicines and thus suppress the manufacture and sale of competing generic products. This requirement massively aggravates poverty by increasing the cost of medicines that poor people, far more vulnerable to disease, have much greater need for. Often, poor people cannot afford the medicines they would have been able to buy in the absence of TRIPS and then spend money on inferior (often counterfeit) products, or else go without medicine altogether, and suffer chronic disease or even premature death as a result, with devastating effects on their family's livelihood.48

As an example of the influence of supranational rules mediated by competition, consider that the WTO Treaty, while mandating open and competitive global markets, contains no uniform labor standards that would protect workers from abusive and stressful working conditions, from absurdly low wages, or from excessive working hours. It thereby draws poor countries into a vicious "race to the bottom" where they, competing for foreign investment, must outbid one another by offering ever more exploitable workforces. Under the conditions of WTO globalization, workers cannot resist such a deterioration of their terms of employment because, if they succeed in securing more humane working conditions for themselves, many of them will end up unemployed as jobs are moved abroad.

Massive increases in domestic inequality are to be expected, then, in developing countries. And we do indeed find this phenomenon in nearly all developing countries for which good data are available, countries as diverse as Argentina, Bangladesh, Costa Rica, the Dominican Republic, Ecuador, Hungary and Jamaica. ${ }^{49}$

China is an especially interesting case, because it contains nearly a fifth of humanity and is the leading poster child of globalization. During the 1990-2004 period, China reportedly achieved spectacular 236\% growth in per capita gross national income. ${ }^{50}$ But the same period also saw a stunning increase in inequality. While the income share of the top tenth rose from $25 \%$ to $35 \%$, that of the poorest fifth fell from $7.3 \%$ to $4.3 \% .51$ This means that the ratio of the average incomes of these two groups increased from 6.8

48. See Thomas Pogge, The Health Impact Fund and Its Justification by Appeal to Human Rights, 40 J. OF SOC. PHIL. 4, 542 (2009).

49. UNITED NATIONS UNIV. WORLd INSTITUTE FOR DEV. ECON. RESEARCH [UNU-WIDER], WORLD INCOME INEQUALITY DATABASE V2.0C (May 2008), http:/ / www.wider.unu.edu/research/Database/en_GB/ database.

50. Calculated from World Bank data by dividing each year's GNI (in current Yuan) by China's population that year, then using China's GDP deflator to convert into constant 2005 Yuan.

51. Distribution data for 1990 from the World Bank as cited in Camelia Minoiu \& Sanjay Reddy, Chinese Poverty: Assessing the Impact of Alternative Assumptions, 54 REVIEW INCOME \& WEALTH 4, 572, 577, tbl.1 (2008). Distribution data for 2004 is from WORLD BANK, WORLD DEVELOPMENT INDICATORS 2008 68, tbl.2.8 (2008). 
to 16.3 as average income in the top tenth rose by $370 \%$ while average income in the poorest fifth rose by only $98 \%$. To be sure, an income gain of $98 \%$ over fourteen years is not bad at all. But China's poor paid a high price for it in terms of marginalization, humiliation, and oppression by the emerging economic elite whose greatly expanded share of Chinese household income gives them much greater opportunities to influence political decisions, to give unfair advantages to their children, and to dominate the poor in direct personal interactions. They would have been much better off with more equal economic growth, even if this would have been somewhat less rapid.

We find a similar phenomenon in the other leading country of the twenty-first century, the United States. In line with the Kuznets Curve hypothesis, the U.S. experienced gradual income equalization from the beginning of the Great Depression until the beginning of the current globalization period. Contrary to the Kuznets hypothesis, this period was followed, however, by a dramatic income polarization that progressed most rapidly in the 1990s. The nearby table tells the story, and the data from the Internal Revenue Service (more fine-grained than those available for China) show, in particular, that the relative gains were heavily concentrated at the very top, where a mere 400,000 now earn as much as the poorest 150 million. The top $0.01 \%$ of U.S. households (ca. 14,400 tax returns) quadrupled their share of U.S. household income and increased their advantage in average income over the poorer half of Americans six-fold, from $375: 1$ to $2214: 1$. The top ventile (one twentieth) of the population is the only one that gained ground; each of the lower 19 ventiles saw its share of U.S. household income decline, and these relative losses were greatest at the bottom. ${ }^{52}$

52. The top five rows of the table present data from Facundo Alvaredo, Tony Atkinson, Thomas Piketty \& Emmanuel Saez, WORLD TOP INCOMES DATABASE, http://gmond.parisschoolofeconomics.eu/topincomes/ (last visited Apr. 2, 2011). The remaining three rows present data provided by Mark Robyn \& Gerald Prante, Summary of Latest Federal Individual Income Tax Data, TAX FOUND. tbl.5 (Oct. 6, 2010), www.taxfoundation.org/publications/show/250.html. Because the data come from different sources, columns 2-4 do not quite sum up correctly. But this should not disturb the table's point which is to display the rapid polarization of the U.S. income distribution documented in the rightmost column. 


\begin{tabular}{|c|c|c|c|c|c|}
\hline $\begin{array}{l}\text { Segment of } \\
\text { U.S. } \\
\text { Population }\end{array}$ & $\begin{array}{l}\text { Share of } \\
\text { US } \\
\text { Household } \\
\text { Income } \\
1928 / 29\end{array}$ & $\begin{array}{l}\text { Share of } \\
\text { US } \\
\text { Household } \\
\text { Income } \\
1980 / 81\end{array}$ & $\begin{array}{l}\text { Share of } \\
\text { US } \\
\text { Household } \\
\text { Income } \\
2007 / 08\end{array}$ & $\begin{array}{l}\text { Absolute } \\
\text { Change } \\
\text { in Income } \\
\text { Share } \\
1980 / 1- \\
2007 / 8\end{array}$ & $\begin{array}{l}\text { Relative } \\
\text { Change in } \\
\text { Income } \\
\text { Share }\end{array}$ \\
\hline $\begin{array}{l}\text { Richest } \\
0.01 \%\end{array}$ & 5.01 & 1.33 & 5.54 & +4.21 & $+318 \%$ \\
\hline Next $0.09 \%$ & 6.22 & 2.17 & 5.81 & +3.64 & $+168 \%$ \\
\hline Next $0.9 \%$ & 11.92 & 6.53 & 10.89 & +4.36 & $+67 \%$ \\
\hline Next $4 \%$ & 14.38 & 13.09 & 15.37 & +2.28 & $+17 \%$ \\
\hline Next $5 \%$ & 10.48 & 11.48 & 11.39 & -0.09 & $-1 \%$ \\
\hline Next $15 \%$ & & 24.63 & 21.14 & -3.49 & $-14 \%$ \\
\hline $\begin{array}{l}\text { Second } \\
\text { Quarter }\end{array}$ & & 25.61 & 19.45 & -6.16 & $-24 \%$ \\
\hline $\begin{array}{l}\text { Poorest } \\
\text { Half }\end{array}$ & & 17.72 & 12.51 & -5.21 & $-29 \%$ \\
\hline
\end{tabular}

This income polarization in the U.S., and the consequent economic and political marginalization of the U.S. poor, underscore the point that increasing intra-national inequality is a widespread phenomenon that, while certainly influenced by domestic factors and resistible by domestic political processes, is favored and facilitated by the WTO globalization of the last decades. U.S. polarization can moreover highlight a useful political point: if the poorest ninety percent of the U.S. population had a better understanding of their own interests, they would be potential partners in a coalition aimed at democratizing globalization: aimed at reducing the nearmonopolistic power of a small global elite that is now steering the evolution of the supranational institutional architecture. To win them as allies we can appeal to their interests, but also, of course, to their commitment to human rights which are the core theme of this article. Let me conclude then by highlighting some of the main features of the present supranational institutional arrangements that are especially detrimental to the realization of human rights.

I give this account in opposition to the usual rosy story which, if it acknowledges the massive persistence of severe poverty at all, explains it by two factors: corrupt and oppressive regimes in many poor countries and the 'leaky bucket' of development assistance. Both of these explanations have an element of truth. But the first fails to explain the high prevalence of corrupt and oppressive regimes, and the second fails to explain why the income share of the poor is falling, and rapidly so. 
My own explanation can redeploy the metaphor: the assets of the poor are like a leaky bucket, continuously depleted by massive outflows that overwhelm the effects of development assistance, which, in any case, are puny. We take great pride in our assistance, boasting, for example, of the billions we spend annually on assistance to poor countries. Yet we ignore the vastly larger amounts that we extract from the poor without compensation. Consider the following examples.

First, affluent countries and their firms buy huge quantities of natural resources from the rulers of developing countries without regard for how such leaders came to power and how they exercise power. In many cases, this amounts to collaboration in the theft of these resources from their owners: the country's people. It also enriches their oppressors, thereby entrenching the oppression: tyrants sell us the natural resources of their victims and then use the proceeds to buy the weapons they need to keep themselves in power. ${ }^{53}$

Second, affluent countries and their banks lend money to such rulers and compel the country's people to repay it even after the ruler is gone. Many poor populations are still repaying debts incurred, against their will, by dictators such as Suharto in Indonesia, Mobutu in the Democratic Republic of the Congo, and Abacha in Nigeria. Again, we are participating in theft: the unilateral imposition of debt burdens on impoverished populations.

Third, affluent countries facilitate the embezzlement of funds by public officials in less developed countries by allowing their banks to accept such funds. This complicity could easily be avoided: banks are already under strict reporting requirements with regard to funds suspected of being related to terrorism or drug trafficking. Yet Western banks still eagerly accept and manage embezzled funds, with governments ensuring that their banks remain attractive for such illicit deposits. Global Financial Integrity (GFI) estimates that less developed countries have in this way lost at least $\$ 342$ billion annually during the $2000-2008$ period. ${ }^{54}$

Fourth, affluent countries facilitate tax evasion in the less developed countries through lax accounting standards for multinational corporations. Since they are not required to do country-by-country reporting, such corporations can easily manipulate transfer prices among their subsidiaries to concentrate their profits where they are taxed the least. As a result, they may report no profit in the countries in which they extract, manufacture or sell goods or services, having their worldwide profits taxed instead in some tax haven where they only have a paper presence. GFI estimates that, during the 2002-2006 period, trade mispricing deprived less developed

53. See Pogge, World POverty And Human Rights, supra note 28, ch. 6; Leif Wenar, Property Rights and the Resource Curse, 36 PHIL. \& PUB. AfF. 2-32 (2008).

54. Dev Kar \& Karly Curcio, Global Fin. Integrity, Illicit Financial Flows from DEVELOPING COUNTRIES: 2000-2009 (2011). For comparison, official development assistance during this period averaged $\$ 87$ billion annually, of which only $\$ 9$ billion was allocated to "basic social services." Millennium Development Goal Indicators, UNITED NATIONS, http:/ / unstats.un.org/unsd/mdg/Search.aspx?q=bss\% 20oda (last visited March 4, 2011). 
countries of $\$ 98.4$ billion per annum in tax revenues. .55

Fifth, affluent countries account for a disproportionate share of global pollution. Their emissions are prime contributors to serious health hazards, extreme weather events, rising sea levels, and climate change, to which poor populations are especially vulnerable. A recent report by the Global Humanitarian Forum estimated that climate change is already seriously affecting 325 million people and is annually causing $\$ 125$ billion in economic losses, as well as 300,000 deaths, of which $99 \%$ are in less developed countries. ${ }^{56}$

Finally, affluent countries have created a global trading regime that is supposed to release large collective gains through free and open markets. The regime is rigged; it permits rich states to continue to protect their markets through tariffs and anti-dumping duties and to gain larger world market shares through export credits and subsidies (including about \$265 billion annually in agriculture alone) that poor countries cannot afford to match. ${ }^{57}$ Since production is much more labor-intensive in poor than in affluent countries, such protectionist measures destroy many more jobs than they create.

\section{What Ought We to Do?}

Taken together, these supranational institutional factors generate a massive headwind against the poor. ${ }^{58}$ This headwind overwhelms the effects of public and private foreign aid, perpetuating the exclusion of the poor from effective participation in the globalized economy and their inability to benefit proportionately from global economic growth. This problem may be solvable through huge increases in development aid, but such continuous compensation is neither cost-effective nor sustainable. It is far better to develop institutional reforms that would reduce the headwind, and eventually turn it off. This would mean seeing the world poverty problem not as a specialist concern at the margins of grand politics but as an important consideration in all decisions related to institutional design.

The world's leading governments could mainstream the imperative of poverty avoidance in this way. But Western governments are unlikely to do this unless there is voter demand or at least voter approval. As of now, the opposite is the case. Even while the hardships suffered by poor people are rising (partly as a result of the U.S.-caused Global Financial Crisis),

55. Ann Hollingshead, Global Fin. Integrity, The Implied Tax Revenue Loss from TRADE MisPRICING 15, tbl.2 (2010).

56. Global Humanitarian Forum, The ANATOMy OF A Silent CRisis 1, 78 (2009).

57. ORg. For ECON. Co-OPERATION AND Dev't, Agricultural POlicies in OECD COUNTRIES 13 (2009).

58. That this headwind is at most weak and uncertain has been forcefully argued by Cohen. Joshua Cohen, Philosophy, Social Science, Global Poverty, in THOMAS POGGE AND HIS CRITICS, supra note 45, at 18-45. See also my reply. THOMAS POGGE, Responses to the Critics in THOMAS POGGE AND His CRITICS, supra note 45, at 175-250. With luck, this dispute will stimulate more and better empirical research on what the effects of various supranational institutional design decisions actually are. 
voters in the United States are putting foreign aid at the bottom of the list of expenditures to be preserved. ${ }^{9}$ Voters in Continental Europe are somewhat more supportive of foreign aid, with voters in Germany, Italy, France, and Spain holding that more of the needed budget cuts should come out of the military budget. ${ }^{60}$ These more supportive voter attitudes are reflected in higher European outlays for official development assistance (ODA), which are $0.45 \%$ of gross national income versus $0.20 \%$ for the United States. ${ }^{61}$ Both rates are far below the Western promise of the 1970s to bring ODA rates up to $0.70 \%$ - a promise that only five small countries (Denmark, Sweden, Norway, Luxembourg, and the Netherlands) have been honoring. It should also be noted that much foreign aid is spent for the benefit of domestic exporters or "friendly" governments; out of $\$ 120$ billion spent annually on ODA, only about $\$ 15.5$ billion is spent on "basic social services," that is, on reducing poverty or its effects. ${ }^{62}$

Citizen attitudes clearly matter. If citizens of Western states cared about the avoidance of poverty, then so would their politicians. But an individual citizen may still feel powerless to change anything and may then reject any responsibility for the massive persistence of severe poverty. This rejection clearly could not excuse a majority of citizens. Given the stakes, the members of such a majority should organize themselves or otherwise ensure that politicians understand that they must seriously address the world poverty problem if they want to succeed in politics. But if - as is actually the case - a large majority of one's fellow citizens is not ready to prioritize the world poverty problem, then there may indeed be little that a few willing citizens can do to change their country's policies and posture in international negotiations about supranational institutional design. Should citizens in this situation be considered implicated in their country's human rights violation even if they cannot prevent it?

One might argue for an affirmative answer on the following ground: such citizens could emigrate to one of the poorer countries, thereby disconnecting themselves from their erstwhile country's policies and marginally weakening this country. Emigration may indeed be a plausible decision in cases of great injustice - it made sense, for instance, for Herbert Ernst Karl Frahm (the later Willy Brandt) to leave Germany as the Nazis were consolidating power. But in developed Western societies today, democratic institutions remain basically intact, and efforts to stir the

59. A recent CNN poll (Jan. 21-23, 2011) found that eighty-one percent of Americans are in favor of reductions in foreign aid. CNN, OPINION RESEARCH CORPORATION POLL - JAN. 21 TO 23, 201117 (2011), available at http:/ / i2.cdn.turner.com/cnn/2011/images/01/25/rel2d.pdf.

60. Tony Barber, Strong Public Support for Spending Cuts Across Europe, FIN. TIMES, July 12, 2010, http://www.ft.com/cms/s/0/8f9e61c0-8ce2-11df-bad7-00144feab49a.html\#axzz1Fbg LKgVc (last visited Mar. 4, 2011).

61. See Net ODA as Percentage of OECD/DAC Donors GNI, U.N. STATISTICS DIV. (June 23, 2010), http:/ / unstats.un.org/unsd/mdg/Search.aspx?q=bss\%20oda.

62. See Net ODA, Million US\$, U.N. STATISTICS DIV. (June 23, 2010), http://unstats.un.org/unsd/mdg/SeriesDetail.aspx?srid=569\&crid=; ODA to Basic Social Services, Million US\$, U.N. STATISTICS DIV. (June 23, 2010), http:// unstats.un.org/unsd/mdg/SeriesDetail.aspx? srid=592\&crid=. 
conscience of one's compatriots are not futile. Moreover, there is a far better way for citizens to avoid sharing responsibility for the human rights violations their government is committing in their name. Citizens can compensate for a share of the harm for which their country is responsible by, for example, supporting effective international agencies or nongovernmental organizations. Such compensation is a much better option than emigration for two reasons: it is typically less burdensome for citizens, and it also reduces the human rights deficit in which these citizens are implicated. To make room for this compensation option, our human-rightscorrelative negative duty in regard to social institutions should then be amended. We have a duty not to collaborate in the design or imposition of social institutions that foreseeably cause a human-rights deficit that is reasonably avoidable through better institutions - unless we fully compensate for our fair share of the avoidable human rights deficit.

How might compensation work? Suppose one accepts the earlier estimate that those lacking an adequate standard of living in 2005 would have needed another two percent of global household income to reach this low level of sufficiency. And suppose that your household's per capita income in 2005 was about $\$ 15,000$, placing you in the middle of the second ventile. Since the top two ventiles in 2005 had $68.54 \%$ of global household income, a transfer of $2.9 \%$ of their collective income to the poor would have been theoretically sufficient to eradicate severe poverty. Had you in 2005 reduced the global poverty gap by $\$ 435(2.9 \%$ of $\$ 15,000)$, then you would have been sure to have compensated for your fair share of the harm that we, through our governments, are collectively imposing on the world's poor. 63

\section{CONCLUSION}

To show that we are indeed violating the human rights of the world's poor, I have proceeded in two main steps. Part II set forth a conception of what it means to violate a human right, arguing that "human rights violation" is a relational predicate, involving right holders as well as duty bearers, with the latter playing an active role in causing the human rights of the former to be unfulfilled. Widely neglected is one very common kind of

63. Of course this calculation should be refined in various ways. First, even a just supranational institutional order, carefully designed toward human rights realization, would not avoid poverty completely, so we may not be collectively responsible for the entire poverty gap. Second, some have job-related reasons to live in an area with high prices (especially for shelter) which may reduce their fair share. Third, some people poorer than we are, those in the third and fourth ventiles at least, might also be expected to make compensating contributions, which would slightly dilute our fair share. Fourth, people richer than we are should be expected to contribute more than a proportional $(2.9 \%)$ share of their incomes. You can easily argue your way down to $\$ 300$. But in view of the horrendous deprivations suffered by the world's poor people, in view of the near-universal failure of our peers to make the required compensating contribution, and in view of our undeserved good fortune to be born among the privileged (and perhaps to be more privileged than anyone would be under just institutional arrangements), we have every reason to err on the side of overpayment. 
such violations involving the design and imposition of institutional arrangements that foreseeably and avoidably cause some human beings to lack secure access to the objects of their human rights. Just as one is actively harming people when one takes on the office of lifeguard and then fails to do one's job, so we are actively harming people when we seize the authority to design and impose social institutions and then fail to shape these institutions so that human rights are realized under them insofar as this is reasonably possible. As argued in Part III, we violate the human rights of billions of poor people by collaborating in the imposition of a supranational institutional scheme that foreseeably produces massive and reasonably avoidable human rights deficits.

It is easy to walk away from this conclusion with the comment that its empirical support has not been established beyond any doubt. As I indicated above, it is certainly possible that the global human rights deficit would have been at least as large as it is under any feasible alternative design of supranational institutional arrangements. But to live comfortably with the belief that we have only positive assistance duties toward the world's poor, we need more than a slight doubt of my conclusion. This is especially true in light of the amazing lack of serious unbiased inquiry into the effects of existing global institutional arrangements. Are we going to tell the poor majority of our contemporaries that, as we have not carefully examined the causal effects of the institutional arrangements we are (in collaboration with their ruling elites) imposing on the world, we cannot be certain that these arrangements are doing massive avoidable harm - and that we may therefore reject as insufficiently corroborated the claim that we are violating their human rights? With a lot of evidence supporting the claim that supranational institutional arrangements we are involved in imposing contribute greatly to the persistence of the huge current human rights deficit, we ought to press for more careful study of these arrangements and their effect and for feasible reforms that make these arrangements more protective of the poor. Each of us should also do enough toward protecting poor people to be confident that one is fully compensating for one's fair share of the human rights deficit that we together cause. 